\title{
Geothermal Potential Based on Physical Characteristics of the Region (Case Study: Mount Karang, Pandeglang Regency and Banten Province)
}

\author{
Fhillipo Russel ${ }^{1, *}$, Astrid Damayanti ${ }^{2}$, and Tjiong Giok Pin ${ }^{2}$ \\ ${ }^{1}$ Bachelor Program of Geography, University Of Indonesia, Depok - Indonesia \\ ${ }^{2}$ Department of Geography, Faculty of Mathematic and Natural Science, University Of Indonesia, Semarang - Indonesia
}

\begin{abstract}
This research is about geothermal potential of Mount Karang, Banten Province which is based on the characteristics of the region. This research method used is geochemistry sample of hot springs and integrated with GIS method for spatial of geothermal potential. Based on the geothermal potential, Mount Karang is divided into three regions, ie high potential, normal potential, and low potential. The high geothermal potential region covers an area of $24.16 \mathrm{Km}^{2}$ and which there are Cisolong and Banjar 2 hot springs. The normal potential covers Kawah hot spring. Index of the fault of Mount Karang region is one of the significant physical characteristics to determine geothermal potential.
\end{abstract}

\section{Introduction}

Indonesia is surrounded by active volcanoes in almost every region. This makes Indonesia the most potential country to have renewable energy in the form of geothermal. Mount Karang is a volcano that has volcanic activity. The hot springs in Mount Karang become a manifestation that the location has geothermal potential. According to [1] to determine whether a mainstream has a commercial geothermal potential or not, a study of the type of hot springs is required. Testing this type of hot springs using geochemical methods by looking at chemical elements $\mathrm{Na}, \mathrm{K}$ and $\mathrm{Mg}$. Testing the element will produce three types of hot springs namely Immature Water, Partial Equilibrium and Full Equilibrium. Important to note that a geothermal resource is part of a geologic system where geologic factors such as lithology, faults, fractures, stress field, diagenesis, rock mechanics, fluid chemistry and geochemistry control key parameters [2].

The geothermal fluid contained in the hydrothermal reservoir of a manifestation derived from surface water includes rainfall that enters the surface and is heated $[3,4]$. The reservoir temperature is obtained by using geochemical method. Processed data consist of chemical data of hot water manifestation, isotope data, soil chemical and soil gas data [5]. The data is used to assess the possible development of geothermal resources that include various parameters such as resource size, temperature estimates, and formation permeability [6]. The concept of permeability of rock formations in relation to geothermal, is oriented in a proportional manner, namely primary permeability and secondary permeability [7]. Primary permeability includes rocks, rock layer contacts, misalignment and ancient solution features that are also overall known as stratigraphic approaches. Secondary permeability includes fractures, hydraulic fracturing, joints and hydrothermal leaching. The more fault or fault there will be many hot springs that appear to the surface [8]. The concept of permeability is also an indication of how the geothermal process occurs. According to [9] meteoric water in permeable and porous rocks is heated and hot water is trapped to form a geothermal reservoir.

The geological structure that controls Mount Karang in Pandeglang and Serang regencies is the same structure that is Maramang fault structures that trails northwestsoutheast, which is a continuation of the regional fault structure in southern Lampung [10] but according to [11] it directed west-east. The purpose of this research is to analyze the geothermal potential areas and the relationship between the physical characteristics of the region as a reference for geothermal exploration.

\section{Methodology}

The parameters used are physical characteristics of geothermal area and geothermal potential distribution area. Physical characteristics of the area included in the study are the surface temperature of the soil, altitude and slope, type of parent rock (lithology) and fracture density. Geothermal potential is determined by the distance between the manifestations, the type of hot springs and the reservoir temperature. Distribution of geothermal potential areas is analyzed by overlay and scoring methods. 
The distance between manifestation is obtained from field survey, then plotted and processed using ArcGIS 10.2 software and analyzed using buffer with range $<500$ meter, $500-3000 \mathrm{~m}$ and $>3000 \mathrm{~m}$ [12].

The reservoir temperature was obtained from the calculation using the $[1,13]$ reservoir temperature equation based on the $\mathrm{Na}$, $\mathrm{K}$ element contained from the hot springs sample.

$\mathrm{T}=[1390 /(1.750+\log (\mathrm{Na} / \mathrm{K}))]-273.15$

Hot springs were analyzed from the percentages of $\mathrm{Na}$, $\mathrm{K}$ and $\mathrm{Mg}$ elements treated with the following [1,14] equation:

$$
\begin{aligned}
& \mathrm{S}=([\mathrm{Na}] / 1000)+([\mathrm{K}] / 100)+[\mathrm{Mg}]^{1 / 2} \\
& \% \mathrm{Na}=[\mathrm{Na}] / 10 . \mathrm{S} \\
& \% \mathrm{~K}=[\mathrm{K}] / \mathrm{S} \\
& \% \mathrm{Mg}=[\mathrm{Mg}]^{1 / 2} / \mathrm{S}
\end{aligned}
$$

The percentage value of these elements is plotted into Ternary Diagram using software Rockware 14.

The surface temperature of the soil is processed from Landsat 8 (band 11) and Landsat 5 (band 6) image using Envi 4.7. Temperature data used 1996-2016 and divided into three periods namely in 1996, 2007 and 2016. Equations used in data processing is

$\mathrm{T}=\mathrm{K} 2 / \ln \left(\mathrm{K} 1 / \mathrm{CV}_{\mathrm{R} 2}+1\right)$

Legend :

$\mathrm{T}=$ Land Surface Temperature

$\mathrm{K} 1 \& \mathrm{~K} 2=$ Coeffiecient

$\mathrm{CV}=$ The radiance value on the thermal band

Altitude and slope data were obtained from DEM image, and processed using Envi software. Litologi data obtained from geological map sheet with scale 1: 100.000. Fraction density is calculated using the Fault Fracturing Density method in ArcGIS 10.2. Bands used to analyze fault and straightness are composites of bands 5,6 and 7 on Landsat 8 image.

\section{Geothermal Manifestation on Mount Karang}

There are seven geothermal manifestations in the form of hot springs that appear on Mount Karang. The hot springs have temperatures ranging from $400 \mathrm{C}$ to $740 \mathrm{C}$. The results of elemental analysis of $\mathrm{Na}, \mathrm{K}$ and $\mathrm{Mg}$ from hot springs sample showed reservoir temperature manifestation ranged from $117.910 \mathrm{C}$ to $528.180 \mathrm{C}$. Based on the interval $[2,15]$ the temperature range includes a low classification $(<1250 \mathrm{C})$, medium $(125-2250 \mathrm{C})$, high

\begin{tabular}{|c|c|c|c|c|c|}
\hline \multirow{2}{*}{$\begin{array}{l}\text { Name of } \\
\text { Hot } \\
\text { Spring }\end{array}$} & \multicolumn{3}{|c|}{$\begin{array}{l}\text { Chemical } \\
(\mathrm{ppm})\end{array}$} & \multirow{2}{*}{$\begin{array}{l}\text { Hot } \\
\text { spring } \\
\text { Temp } \\
\text { eratur } \\
\mathrm{e}^{0} \mathrm{C}\end{array}$} & \multirow{2}{*}{$\begin{array}{l}\text { Reservoir } \\
\text { Temperat } \\
\text { ure }{ }^{0} \mathrm{C}\end{array}$} \\
\hline & $\mathrm{Na}$ & $\mathrm{K}$ & $\mathrm{Mg}$ & & \\
\hline Crater 1 & 8.2 & 4.76 & 8.6 & $40^{\circ} \mathrm{C}$ & $426.68^{\circ} \mathrm{C}$ \\
\hline Crater 2 & 7.74 & 4.15 & 9.17 & $74^{0} \mathrm{C}$ & $414.73^{\circ} \mathrm{C}$ \\
\hline Crater 3 & 3.05 & 3.16 & 1.7 & $71^{\circ} \mathrm{C}$ & $528.18^{\circ} \mathrm{C}$ \\
\hline $\begin{array}{l}\text { Cisolong } \\
1\end{array}$ & 45.29 & 31.39 & 25.91 & $55^{0} \mathrm{C}$ & $454.90^{\circ} \mathrm{C}$ \\
\hline $\begin{array}{l}\text { Cisolong } \\
2\end{array}$ & 44.34 & 35.71 & 26.19 & $63^{0} \mathrm{C}$ & $480.64^{\circ} \mathrm{C}$ \\
\hline Banjar 1 & 34.42 & 0.54 & 2.86 & $33^{0} \mathrm{C}$ & $117.91^{\circ} \mathrm{C}$ \\
\hline Banjar 2 & 45.84 & 3.68 & 3.45 & $32^{0} \mathrm{C}$ & $225.36^{\circ} \mathrm{C}$ \\
\hline
\end{tabular}
$(>2250 \mathrm{C})$ and the full information on the table 1 .
Table 1. Identification of Geothermal Manifestations in Mount 4

The determination of the type of hot springs provides information on how the hydrothermal system is in a manifestation, so it can know the equilibrium of water in the rock type. Based on Ternary Diagram (Figure 1), hot springs belonging to the Immature Water type are hot springs Craters 1, 2 and 3 and Cisolong 1 and 2 . Immature Water processes occur because rocks that store heat from beneath the Earth's surface experience the pressure and temperature Very high but before the vapor flow up to the top, the water vapor is already mixed with surface water (Meteoric Water). It is in accordance with opinion [16] G. Karang area is underlain by a concealed outflow of thermal water that has been diluted by groundwater infiltration. Banjar 2 hot springs is a type of Partial Equilibrium hot springs. This type of hot springs is very little affected by surface water flow. Banjar 1 hot springs include Full Equilibrium type which indicates that the reservoir temperature is not completely mixed with surface water.

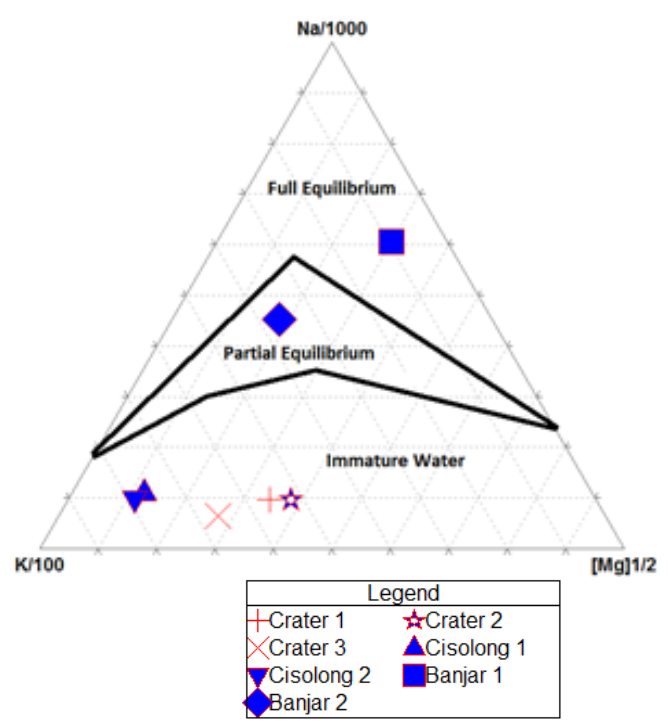

Fig 1. Ternary Diagram (Data Processing, 2017)

The distance between the manifestations indicates the geothermal potential. The closer the geothermal potential is higher [12]. The area of high geothermal potential 
exists between Crater 1 hot springs with Crater 2 and Cisolong 1 with Cisolong 2. The area between Cisolong hot springs with Banjar becomes a low geothermal potential region.

\section{Physical Characteristics of Geothermal Potential Areas in Mount Karang}

The highest mean surface temperature is $20.68^{\circ} \mathrm{C}$ in Banjar 1 hot springs and the lowest is $15.13^{\circ} \mathrm{C}$ in hot springs Crater 1. Banjar 1 hot springs has low reservoir temperature while hot springs Crater 1 has a reservoir temperature With high classification. This is different from the results of research [17]. Their research on Mount Salak indicates that geothermal-manifested regions typically have high surface temperatures. The anomaly occurs because in the hot springs Crater 1 is surrounded by dense forest and its water type is also Immature Water. While in Banjar 1 hot springs the anomaly can occur due to Full equilibrium eye type (Figure 1).

Discussion of morphological units with geothermal potential is closely related to the accessibility of geothermal exploration. Mount Karang has steep mountainous morphology units, steep mountains, mid ramps, mid-wavy and lowlands. The steep mountain morphology unit is a difficult area to reach, so it costs a lot to explore. On the other hand, in lowland areas with high accessibility and low exploration costs but low geothermal potential. So a morphological unit that has high geothermal potential to be explored is a mid-wavy and mid ramp morphological unit. In Mount

Karang area which has mid-wavy and mid-ramped morphology units located in Banjar 2 hot springs and Cisolong 1 and 2 hot springs.

The hot springs emerging to the soil surface are caused by fractures due to fractures in areas that have hydrothermal activity. The water flow beneath the surface will be heated by volcanic activity so that there is a flow of convection currents. Water that has been heated will come to the surface through fractures and water still in normal temperature will flow down to be heated. Fracture density at Mount Karang is divided into two classes, namely low and medium. Low density areas are found in hot springs Craters 1, 2 and 3 and Banjar hot springs 1 and 2 with a density of $0-0.246 \mathrm{~km}^{2}$. The densely populated region is in the hot springs of Cisolong 1 and 2 with a density of $0.246-0.722 \mathrm{~km}^{2}$ (Figure 3.).

The characteristics and extent of the ore deposits and the geothermal fluids depend on the geometry and distribution of faults, fractures and porous media in the caldera and its basement $[18,19,20,21]$. Low fault density has low reservoir temperature and low permeability of rocks and low number of hot springs [14]. However, in hot springs Craters 1,2 and 3 whose low fault density has a high reservoir temperature with a sufficient number of hot springs. (Figure 3). This happens because the existing faults are not captured by the landsat image, and the fault has been covered by lake swamp sediments [22]. The anomaly is also seen from the rose diagram (Figure 2). Figure 2 is a rose diagram showing the direction and dominance of straightness and fracture on Mount Karang. Areas with high permeability are visible in the southwest-Northeast. This is different from the statement from $[11,14]$ as stated in the introduction.

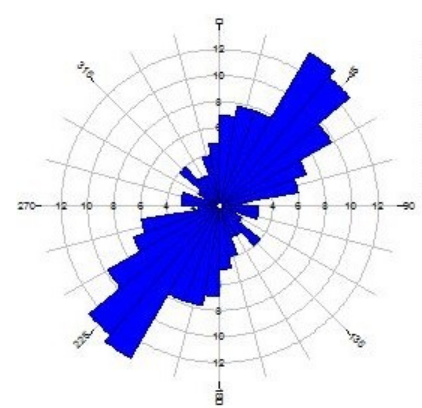

Fig 2. Rose Diagram Fault Density (Data Processing, 2017)

\section{Region of Geothermal Potential Based on Physical Characteristics}

Region of geothermal potential in the coral mountains are divided into three based on physical characteristics, ie low, medium and high. The division of potential areas is based on the results of spatial overlay analysis using 6 variables. These variables are distances between manifestations, hydrothermal activity, ground surface temperature, morphology, lithology and rock permeability.

\subsection{Low Geothermal Potential Region}

Region with low potential are almost all of the research area. The Region of low geothermal potential is 151.13 $\mathrm{km}^{2}$, the geothermal potential area is low based on physical characteristics scattered near the crater and located near the Banjar 1 hot springs. This area has a surface temperature of $19,99^{\circ} \mathrm{C}$. The fault density index in this region belongs to a low classification or if translated in the numbers $0-0.246 \mathrm{~km} / \mathrm{km}^{2}$. The temperature of hot springs in Banjar 1 is $31^{\circ} \mathrm{C}$. Types of rocks that exist in hot springs Banjar 1 has a rock formation of Karang volcanic products with volcanic rock sediment type with the age of Pleitocene rock Holocene.

The morphology of Banjar 1 hot springs is in low flat classification. The chemicals present in hot spring 1 have $34.42 \mathrm{ppm}$ of Sodium element, $0.54 \mathrm{ppm}$ of Potassium element, $2.86 \mathrm{ppm}$ Magnesium element and 12.22 Ppm Sulfur element with reservoir temperature $117,91^{\circ} \mathrm{C}$. With the reservoir temperature included in the low classification but on the plot of Ternary triangle diagram showing that this hot springs are in Full Equilibrium it can be concluded that in the flow of hydrothermal fluid at Banjar 1 hot springs is not so hot, because the reservoir temperature is in the eye Hot water is not high enough so it can be concluded that the volcanic activity 
that occurs in Banjar 1 hot springs is not so active as Crater and Cisolong.

From Pos: $106.0542835446,-6.2797628179$ To Pos: $106.0963444444,-6.3983805555$

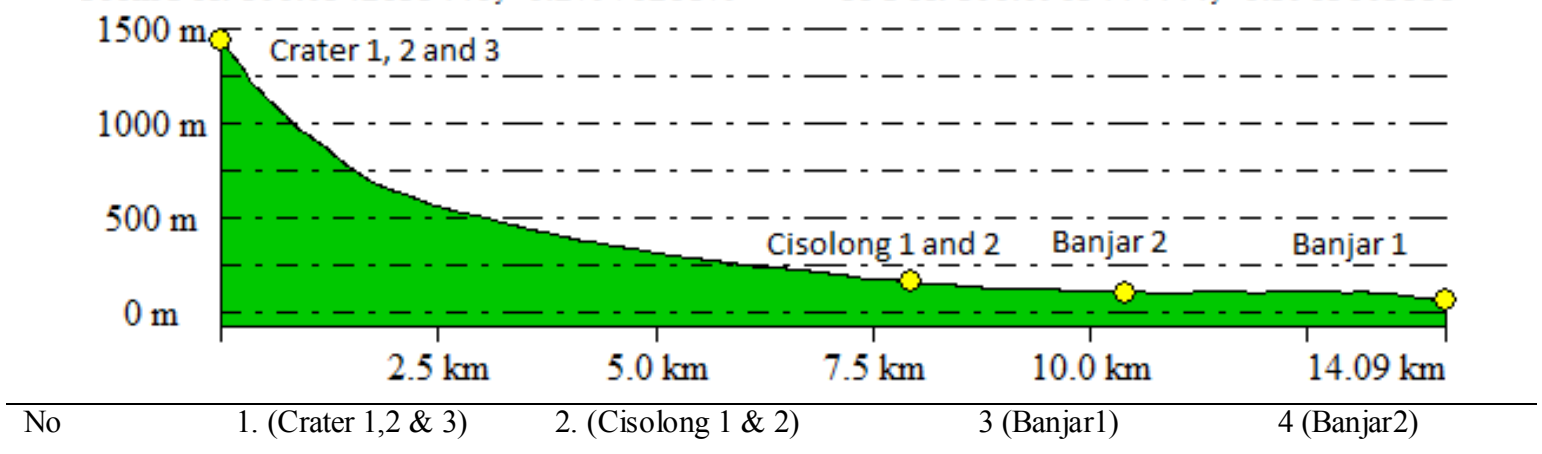

\begin{tabular}{l|ll|ll} 
Lithology & $\begin{array}{l}\text { Young } \\
\text { Karang }\end{array}$ & Lava G & Volcano ProductF \\
& & & \\
& &
\end{tabular}

\begin{tabular}{lllll}
\hline Morphology & Steep mountains & Medium Wavey & Medium Wavey & lowland \\
& & & & \\
Land Soil & $15.13-16.06^{\circ} \mathrm{C}$ & $20.20-20.27^{\circ} \mathrm{C}$ & $19.99^{\circ} \mathrm{C}$ & $20.68^{0} \mathrm{C}$ \\
$\begin{array}{l}\text { Temperature } \\
\text { Fault Density }\end{array}$ & Low & Medium & Low & Low \\
$\begin{array}{l}\text { Reservoir } \\
\text { Temperature }\end{array}$ & $414.73-528.18^{\circ} \mathrm{C}$ & $454.9-480.64^{\circ} \mathrm{C}$ & $117.91^{\circ} \mathrm{C}$ & $225.36^{\circ} \mathrm{C}$ \\
$\begin{array}{l}\text { Type Of Hot } \\
\text { Spring }\end{array}$ & Immature Water & Immature Water & Partial Equilibrium & Full Equilibrium \\
\end{tabular}

Fig. 3. Profile Karang Mount (Data Processing, 2017)

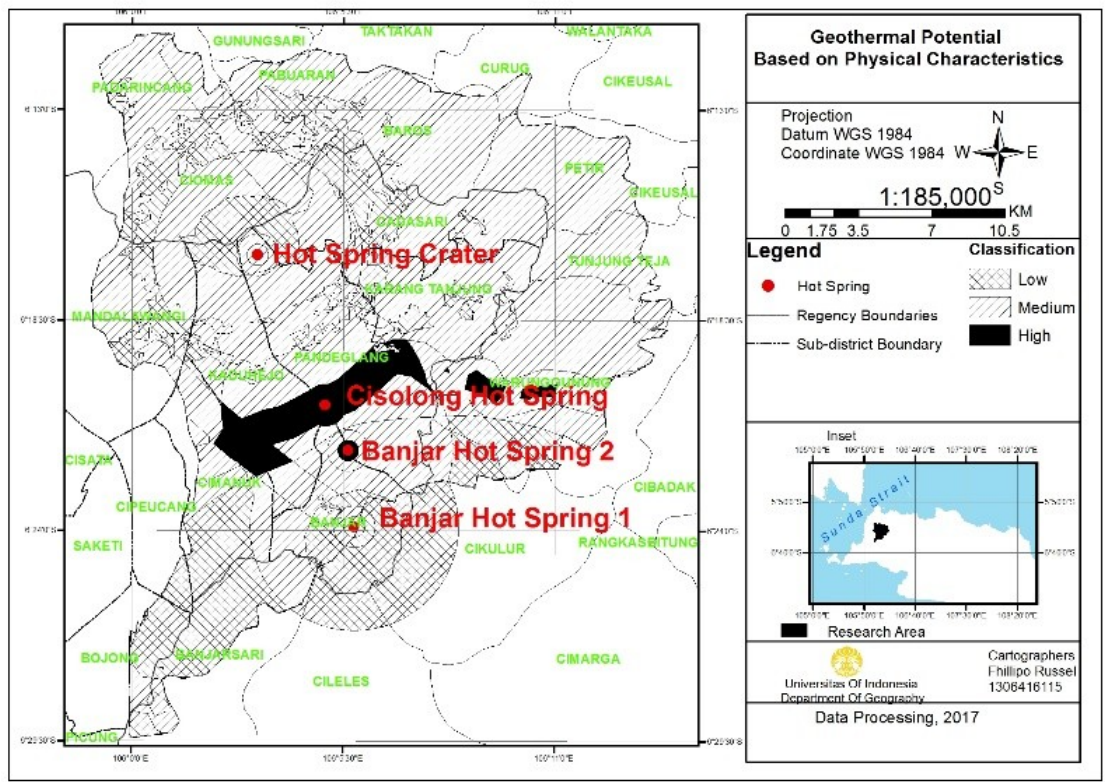

Fig 4. Maps Of Geothermal Potential Based on Physical Characteristics (Data Processing, 2017)

\subsection{Medium Geothermal Potential Region}

Region with geothermal potential are located in Crater hot springs. The area of geothermal potential with medium classification is $386.78 \mathrm{~km}^{2}$. The ground surface temperature in this region is $15,60^{\circ} \mathrm{C}$. The index of fault density and faults in this region has a low classification with an interval of $0-0.246 \mathrm{~km} / \mathrm{km}^{2}$. Types of rocks that exist in the hot springs Crater was the same as Banjar 1 which has a young volcano lava formation Karang with volcanic rock sediment type with the age of Pleitocene rock - Holocene. Morphology in this region 
also includes mid-wavy. The shape of the terrain had started steep and began to steep slopes.

Temperature reservoir in hot springs Craters 1,2 and 3 with temperature 414.73 to $528.18^{0} \mathrm{C}$. In reservoir temperatures, hot springs Craters 1,2 and 3 have reservoir temperatures that are included in the high classification in terms of geothermal potential. With a steep slope, an altitude above $1000 \mathrm{mdpl}$ with a form of steep mountain terrain makes this crater hot springs difficult to be explored and utilized into a power plant because of its existence that is difficult to reach.

This type of hot springs is also a type of hot springs Immature Water where the water on the surface will enter and unite with water vapor so that the steam heat will be reduced. This fact is evidenced by field evidence showing that the ground surface temperature in the area is only $15.6^{\circ} \mathrm{C}$. It can be said that the soil surface temperature is low when compared with other geothermal potential areas that have a high ground surface temperature with a minimum of $25^{\circ} \mathrm{C}$.

\subsection{High Geothermal Potential Region}

Geothermal geothermal potential areas with high classification are located in hot springs Banjar 2 and also Cisolong hot springs 1 and 2. The area with geothermal potential is $24.16 \mathrm{~km}^{2}$. The surface temperature of the land in this potential area is divided into two areas, namely in the area of the crater memilliki ground surface temperature $20,68^{\circ} \mathrm{C}$ and for the Cisolong area has a surface temperature of $20.24^{\circ} \mathrm{C}$. It is interesting there is a ground surface temperature that is in the crater has the lowest temperature than other regions.

This spring type is different, the Banjar 2 hot springs have the Partial Equilibrium hot spring type indicating that the reservoir temperature obtained is still hindered by a small mix of surface water while the Cisolong hot spring type is the Immature water type where the reservoir temperature Is mixed with the surface water so that the actual reservoir temperature of the Cisolong spring is higher than expected in the absence of mixed water and precludes the calculation of reservoir temperature at Cisolong springs.

The density of fault and fault faults and this region is also divided into two, because the area located in Banjar has a low fault density while the density of the area in Cisolong has a moderate fracture density. This moderate density causes reservoir temperatures in Cisolong region to be high due to the reservoir temperature $467.77^{\circ} \mathrm{C}$ with high geothermal potential classification based on reservoir temperature. With its high reservoir temperature, Cisolong area is a high potential area for geothermal energy. The results will be illustrated in Figure 4.

\subsection{Correlation of Geothermal Potential Statistics with Physical Characteristics}

The correlation of geothermal potential with physical characteristics using multiple linear regression method to determine the dominant variable statistically or visible number, thus the number validates the relationship between the geothermal potential and the physical characteristics. Dependent variable is Reservoir Temperature, whereas the independent variables are Rock Type, Fault Density, Morphology and Surface Temperature. Table 2 shows that the summary of the model has been made using multiple linear regression method.

Table 2. Correlation Non Parametric (Data Processing, 2017)

\begin{tabular}{|l|l|l|l|l|l|}
\hline Correlation Non Parametric (Spearman's Rho) \\
\hline $\begin{array}{l}\text { Reservoir } \\
\text { Temperature }\end{array}$ & $\begin{array}{l}\text { Correlation } \\
\text { Coefficient }\end{array}$ & 1 & $.820^{*}$ & - & -0.54 \\
& $\begin{array}{l}\text { Sig. (2- } \\
\text { tailed) }\end{array}$ & & 0.024 & 0.553 & 0.211 \\
\cline { 2 - 6 } & N & 7 & 7 & 7 & 7 \\
& $\begin{array}{l}\text { *. Correlation is significant at the } 0.05 \\
\text { level (2-tailed). }\end{array}$ \\
\hline
\end{tabular}

Table 2 will provide information on the model equations created with surface temperature variables, fracture density and morphology, then other information which variables most influence the reservoir Temperature are the three variables between ground surface temperature, fault density and morphology. The equations created in this study are

$\mathrm{Y}=1210.5-56.3 \mathrm{LST}+147.8 \mathrm{FD}-22.9 \mathrm{M}$

Notes: LST $=$ Land Surface Temperature, RS = Reservoir Temperature, FD = Fault Density, $\mathrm{M}=$ Morphology.

Other information to be seen is the influence of independent variables on the dependent variable in this study, to know it then things that must be seen is the value of sig in table 5.13. The limit value so that the variable has a real effect is $<=0.05$ sig value. Land surface temperature variable has sig value 0.496 and sig value exceeds 0.05 , it shows that ground surface temperature has no significant effect to reservoir temperature. Fault density variables have sig value 0.016 and sig value less than 0.05 , it indicates that fracture density variables have a significant effect on the reservoir temperature variable. Morphological variables have sig value 0.952 and signya value exceeds 0.05 it shows that morphological variables have no significant effect on reservoir temperature. With that information it can be concluded that in the geothermal potential region the physical variable that influences is the fault density. $\mathrm{Y}=1210.5-56.3 \mathrm{LST}+147.8 \mathrm{FD}-22.9 \mathrm{M}$ has meaning in this research. The meaning is that if the reservoir temperature rises 1 degree Celsius then the ground surface temperature will decrease by 56.34 degrees Celsius, the fault density will increase by 147,750 and the morphology will decrease by 22,917 with the constant as reference in the determination in equation of 1210.480 . It shows that if reservoir temperature rises in research area, soil surface temperature and morphology value will decrease while 
the fault density value will increase. These geothermal potential based on physical characteristics in Cisolong with reservoir temperature 467.77 have a mean fracture density value.

\section{Conclusion}

Region with geothermal potential in Mount Karang and surrounding areas based on their physical characteristics are divided into 3 ie with low potential, medium and high. The area with low geothermal potential based on the characteristics of its territory has an area of 151.13 $\mathrm{km}^{2}$ with a ground surface temperature of $19.99^{\circ} \mathrm{C}$, a volcanic lowland morphological unit, a low fault density and a reservoir temperature of $117.91^{\circ} \mathrm{C}$ and has manifestations in Banjar Springs 1. Medium geothermal potential region Ground level 15.13 - $16.06^{\circ} \mathrm{C}$ with medium fault density, morphology unit high volcanic steep mountains with reservoir temperature 414.73 $528.18^{\circ} \mathrm{C}$ and manifestations are in Crater hot springs. Region with high geothermal potential are located in Banjar 2 and Cisolong with an area of $24.16 \mathrm{~km}^{2}$, the physical characteristics of the area has a moderate fault density, surface temperature of $20.2-20.67^{\circ} \mathrm{C}$ with midwavy morphological units and has a temperature reservoir of $225.36-528.18^{\circ} \mathrm{C}$.

The relationship between physical characteristics of the region with geothermal potential has a strong relationship, it is reinforced by spatial analysis and statistical analysis. Based on spatial analysis, areas with high geothermal potential have a moderate fault density value with high reservoir temperature and low geothermal potential having low fault density and low reservoir temperature, whereas based on statistical analysis of the four physical characteristic variables ie surface temperature, Type of rock, fracture density and morphological units only the fault density that affects the value of the reservoir temperature due to its value $<0.05$ which indicates that the fault density is closely related to the reservoir temperature.

The determination of the direction of fault and the dominant fracture in this study directed southwest and northeast, it is different from the research opinion with [16] that directed northwest and southeast and [3] research directed west-east. This shows that in determining the direction of fault and fault not only through remote sensing it is necessary to do field survey to show the direction of fault and fault that exist in a region.

\section{Reference}

1. W.F. Giggenbach, Geochemica Acta 52. pp. 2749 2765. (1988).

2. I. S. Moeck, Elsevier. (2014)

3. 3 Nenny Miryani Saptadji. Karakterisasi reservoir panas bumi. Institut Teknologi Bandung, Bandung. (2009).
4. J. G. White, Economic Geology. pp. 48 - 65. (1967).

5. P. Stelling, L. Shevenell., N. Hinz., M. Coolbaugh., G.Melosh., and W. Cumming, Elsevier, Science Direct. (2016).

6. . Lawless, (eds). Lecture Note. Kingston Morrison. New York. pp. 15- 35. (1996).

7. Browne.P.R.L. Geothermal exploration technology pre-advanced class. Inhouse Training, Cirebon. pp. 1-30. (1996).

8. J.B. Purnomo and T. Pichler, Elsevier. (2014)

9. F.V.D. Meer, C. Hecker, F.V. Ruitenbeek, H.V.D. Werff, C.D. Wijkerslooth, C. Wechsler, Elsevier. (2014)

10. Puslitbang Geologi Provinsi Banten. Kondisi Geologi dan Litologi Wilayah Gunung Karang. Dinas Pertambangan dan Energi Provinsi Banten. Banten. (2013).

11. C. Endyana, F. Hirnawan, Hendarmawan, Mardiana. U, Buletin Sumber daya Geologi Volume 6. (2011).

12. Supriyanto Suparno. Energi panas bumi: A present from the heart of the earth. Universitas Indonesia, Depok. pp. 13 -26. (2009).

13. Yiman Lia, Zhonghe Panga, Fengtian Yang, Lijuan Yuan, Pinghui Tang, western China. Elsevier. (2017)

14. S.W.Y.D. Pambudi, M. Sakur, K. Ismail, D.I. Fajri, D.L. Setijadji, Delineasi daerah prospek panas bumi berdasarkan kelurusan citra landsat dan digital elevation model (DEM) daerah Gunung Lawu, Provinsi Jawa Tengah dan Jawa Timur. Universitas Gadjah Mada, Yogyakarta. (2014).

15. M. P. Hochstein, UNITAR/UNDP Centre for Small Energy Resources. Rome, Italy. (1990).

16. 16 M. P. Hochestein and S. Sudarman, History of geothermal exploration in Indonesia from 1970 to 2000. Elsevier. (2008)

17. Sukendar Putri., Mariasari Bandi., Sasmito. and Wijaya Arwan Putra. Analisis sebaran kawasan potensial panas bumi Gunung Salak dengan suhu permukaan, indeks vegetasi dan geomorfologi. Universitas Diponegoro, Semarang. (2016).

18. L. Guillou Frottier, E.B. Burov, J.-P. Milesi, J. Volcanol. Geotherm. Res. 102, pp. 339-361. (2000)

19. D.W. Pals and P.G. Spry, Petrol. 79,pp. 285307.(2003)

20. J. Stix, B. Kennedy, M. Hannington, H. Gibson, R. Fiske, W. Mueller, J. Franklin, Geology 31, pp. 375-378. (2003)

21. W.U. Mueller, J. Stix, P.L. Corcoran, R. Daigneault, Ore Geol. Rev. 35, pp. 4-46. (2009)

22. BEICIP. Geothermal study, Banten area, West Java. Hydrogeochemical Reportprepared for Pertamina. (1979). 